This is an electronic reprint of the original article. This reprint may differ from the original in pagination and typographic detail.

Author(s): Ruggiero, Salvatore; Onkila, Tiina; Kuittinen, Ville

Title: Realizing the social acceptance of community renewable energy: A process-outcome analysis of stakeholder influence

Year: $\quad 2014$

Version:

Please cite the original version:

Ruggiero, S., Onkila, T., \& Kuittinen, V. (2014). Realizing the social acceptance of community renewable energy: A process-outcome analysis of stakeholder influence. Energy Research and Social Science, 4(December), 53-63.

https://doi.org/10.1016/j.erss.2014.09.001

All material supplied via JYX is protected by copyright and other intellectual property rights, and duplication or sale of all or part of any of the repository collections is not permitted, except that material may be duplicated by you for your research use or educational purposes in electronic or print form. You must obtain permission for any other use. Electronic or print copies may not be offered, whether for sale or otherwise to anyone who is not an authorised user. 


\title{
Realizing the social acceptance of community renewable energy: a process-outcome analysis of stakeholder influence
}

\begin{abstract}
This study shows how stakeholders influence the development of community renewable energy (CRE) schemes and how they are influenced by their outcome. It relies on information collected during 41 structured interviews with local people involved in CRE initiatives in seven regions of Europe. The interviews were thematically analysed to identify different types of stakeholder influence. The findings show that stakeholder influence on CRE schemes take place at three distinct levels: macro, intercommunity and intracommunity. In addition, key stakeholders can support or hinder the development of a project according to whether or not they perceive that the output of the project may benefit or harm them. The study contributes to the research on local renewable energy (RE) development by showing how stakeholders take on multiple roles and how their roles may change from process to outcome. Furthermore, the study reveals the importance of two stakeholder groups: intermediary organizations and local champions. These were groups whose positive influence was crucial in the implementation phase and for whom ad hoc policy could be established.
\end{abstract}

Key words: Community renewable energy; stakeholder influence; process and outcome 


\section{Introduction}

In light of the threat posed by climate change, many are advocating a rapid transition to a sustainable energy system relying completely on clean energy. To achieve this transformation, however, a number of questions need to be addressed. Some of them include whom to involve, how to distribute the costs and benefits in a fair way and on what scale energy provision systems should be designed.

The experience of the last two decades of renewable energy (RE) deployment has demonstrated that large-scale projects led by commercial companies have sometimes been criticized for the way the benefits are distributed and for the lack of fairness in procedural development (Aitken, 2010). These factors have often resulted in opposition by local groups of stakeholders, especially in the case of wind power generation (Cass and Walker, 2009). As a result, a community-based approach to RE generation has recently gained in importance. This approach is generally characterized by small- to medium-scale projects carried out by groups of citizens. According to Walker and Devine-Wright (2008), a community approach includes some form of public involvement in the decision-making process and some type of benefit for the local people. In addition, it can also encompass a form of collective control through ownership models such as a social enterprise or co-ownership with a commercial company (Walker, 2008).

Most of the studies in the field of community renewable energy (CRE) development have focused on determining whether or not community involvement leads to less opposition to RE deployment (McLaren Loring, 2007; Musall and Kuik, 2011; Warren and McFadyen, 2010; Walker et al., 2014; Zoellner et al., 2008). Other research has tried to understand if small-scale 
RE initiatives can contribute to a significant increase in RE capacity (Hain et al., 2005) or promote capacity building (Walker and Devine-Wright, 2008). Yet another stream of research has investigated how local stakeholders perceive the community benefits presented by wind power developers (Bristow et al., 2012; Cass et al., 2010; Munday et al., 2011) and how in turn they contribute to the economic development of rural areas (Li et al., 2013; Phimister and Roberts, 2012; Rogers et al., 2008; Tracey et al., 2005).

Despite this growing body of research, the literature still contains little knowledge about the role and the influence of the stakeholders involved in the establishment of CRE schemes. Finding this information is relevant because the success of a project depends to a great extent on the identification of key stakeholders and the management of the relationships with them (Bourne and Walker, 2005). Earlier attempts have already been made to address this gap. For example, Walker and Devine-Wright (2008) identified two dimensions on which the influence of relevant stakeholders in CRE development could be studied: process and outcome. Nevertheless, more research is needed to identify and understand the interplay of the actors involved in community projects.

In this study, we carry out a stakeholder analysis to identify the people, groups or organizations that may influence, or be influenced by, CRE schemes. More specifically, we answer the question of how stakeholders influence the development of CRE projects (the process dimension) and how they are influenced by their outcome. To accomplish our research task we apply descriptive stakeholder theory (see Donaldson and Preston, 1995) and arrive at a stakeholder classification that explains the roles and the factors that make stakeholders assume 
certain roles in CRE development. We use stakeholder theory for two main reasons. First, in many cases it has proved useful in recognizing and managing relevant stakeholders because it explains "who and what really counts" to an organization (Mitchell et al., 1997, p. 853). Second, in the context of CRE projects, a stakeholder approach to systematically study the roles of key actors has not yet been adopted.

\section{CRE and stakeholder influence}

\subsection{CRE: concept definition}

Although there is growing scientific interest in CRE development, to date no clear definition has been presented of what the term community should include. In general, a community renewable energy project can be described as "an installation of one or more renewable energy technologies in or close to a rural community, with input from members of that community" (Rogers et al., 2008, p. 4217). In the literature this approach is often called community energy (Hoffman and High-Pippert, 2005) or community renewable energy (Walker and Devine-Wright, 2008). In this paper we use the term community renewable energy (CRE), by which we mean RE projects that are highly open and participatory and that aim to deliver their benefits to a local community, as suggested by Walker and Devine-Wrigth (2008). Consequently, those initiatives started by municipalities or local businesses that were not participatory or that did not aim expressly at benefiting local people are not considered here.

\subsection{Stakeholder influence}


Since the publication of Freeman's (1984) Strategic Management: A Stakeholder Approach, the focus of stakeholder theory has been on the interaction and interdependence between a company and its stakeholders (Donaldson and Preston, 1995; Lovio, 2005; Näsi, 1995). In the light of stakeholder theory a firm can only exist through the interaction, transactions and exchanges carried out with its stakeholders (Näsi, 1995). We adopt a general definition of stakeholders as "any group or individual who can affect or is affected by the achievement of the organization's objectives" (Freeman, 1984, p. 46).

Within stakeholder theory, one stream of research has focused on studying stakeholder influence from two perspectives: how stakeholders influence companies (Frooman, 1999) and which strategies companies apply to influence stakeholders (Banerjee and Bonnefous, 2011). In this study, because we are applying Freeman's original stakeholder definition we take a look at both how stakeholders influence CRE and how they are influenced by it.

Concerning stakeholder influence strategies, Frooman (1999) tied stakeholder influence to resource dependency theory. He suggests that the resource relationship determines which of the four types of strategies (direct withholding, direct usage, indirect withholding, or indirect usage) will be used by stakeholders. Others have followed this approach from different perspectives and examined, for example, stakeholder influence on financial performance (Berman et al., 1999; Barnett, 2007), stakeholder influence on decision making (Spitzeck and Hansen, 2010) and how stakeholders may influence companies indirectly through networks (Rowley, 1997). The study of Mitchell et al. (1997) implied that the salience of stakeholders depends on the possession of one to three stakeholder attributes: power, legitimacy and urgency. These attributes define the stakeholder's salience to managers, and thus its influence possibilities. 
The question of how stakeholders are influenced by companies has received less attention. Instead, the research has examined the situations in which the stakeholders feel that their stakeholder group interests or stakeholder group identities are jeopardized and how this experience may lead to mobilization of stakeholders (Rowley and Moldoveanu, 2003). In addition, studies have looked at cases of how stakeholders may experience the negative (environmental) impact of corporate actions (Banerjee and Bonnefous, 2001; Banerjee, 2000). Furthermore, studies have shown how stakeholder power and influence may have a pivotal impact on a project's success or failure (Berardi, 2013; Bourne and Walker, 2005). Berardi, for example, pointed out that the most significant barrier to the adoption of new energy-saving technology is the low influence-capacity of highly motivated stakeholders on the decision.

Freeman (1984) and Mitchell et al. (1997) proposed another interesting aspect connected to stakeholder influence: stakeholder dynamics. Freeman suggested that stakeholder influence is not static but changes over time according to how stakeholders' stakes change. Mitchell et al. (1997) added that stakeholder positions can change from one class to another when their salience increases or decreases.

According to Walker and Devine-Wright (2008), the understanding of CRE revolves around questions of both process and outcome. In this study we adopt a stakeholder framework based on this understanding and look at stakeholder influence with regard to both the process and outcome dimensions of CRE schemes. The process dimension refers to the actors that are involved during the implementation of the project, and the outcome dimension refers to the actors that are influenced by the results of the project. In Walker and Devine-Wright's study, these two 
dimensions are encapsulated in questions of "who is involved and has influence" in the development of a project and "who it is that benefits in economic and social terms" (p. 488). With respect to the latter question, we look at project outcomes in terms of who could possibly benefit from CRE schemes as well as in terms of who could possibly be negatively impacted by them.

\subsection{Stakeholder influence on CRE}

Prior studies in the wider context of environmental management have revealed the strong stakeholder influence on any environmental project in traditional business (Banerjee and Bonnefous, 2011; Delmas and Toffel, 2004; Henriques and Sadorsky, 1999; Sharma and Henriques, 2005). However, in CRE deployment a comprehensive approach to stakeholder analysis has not yet been taken. Though not studied systematically before, some research on CRE has already revealed three types of stakeholder influence.

The first type of influence has been shown by some studies that focused on how CRE projects may be triggered by stakeholder influence, especially by government policies, energy-market factors and local community cultures. When Bomberg and McEwen (2012, p. 436) looked at government policies, they observed that the phenomenon is simultaneously supported and hindered by "structural resources", a term which refers to the broad political context for community energy mobilization. This is supported by Walker et al.'s (2007) more positive view, which suggests that especially social enterprise models in CRE projects have been purposely 
favoured by government policies in the UK to foster the development of the RE market without controverting EU rules on state-aid.

Energy-market factors that trigger CRE projects have been discussed by Buchan (2012) and Okkonen and Suhonen (2010). Okkonen and Suhonen reported that Finnish energy co-operatives were established in the early 1990s when the heating services traditionally provided by the municipalities were privatized. According to Buchan (2012), the generous feed-in tariff and affordable membership costs of co-operatives have been two other important elements favouring the RE co-operatives in Germany.

The influence of local community cultures has been addressed by Buchan (2012), Rogers et al. (2012), Bomberg and McEwen (2012), and Seyfang and Smith (2007). Buchan, Rogers et al., and Bomberg and McEwen suggested that the main drivers for CRE projects are based on the existing community cultures, identities of collective civic action and common views of sustainable development. However, Seyfang and Smith maintained that CRE projects are more a response to unmet social needs and ideology.

The second type of influence has been illustrated by those authors that investigated how CRE projects may benefit stakeholders, especially local communities, and how these projects have larger societal impact in terms of environmental or social sustainability. Concerning the benefits for local communities, Walker and Devine-Wright (2008) concluded that there are different degrees of participation and locally shared benefits in CRE projects, but real community projects are those that have a positive outcome for the local community and that involve high levels of citizen participation. Li et al. (2013) and Phimister and Roberts (2012) suggested that CRE schemes bring primarily economic benefits because community-led initiatives increase rural 
household incomes and welfare by creating economic development. Rogers et al. (2008) and Tracey et al. (2005) provide more detailed descriptions of benefits. Rogers et al. found that residents in rural areas supported community energy projects because they expected that a local energy project could enhance community cohesion, promote sustainable use of natural resources and bring about socioeconomic changes. Tracey et al. noted that community enterprises can bring community renewal and local capacity building. Environmental sustainability benefits of CRE schemes may be obtained because CRE projects can significantly increase the overall RE capacity (Hain et al., 2005), they promote pro-environmental behaviour (Rogers et al., 2012) or they contribute to the expansion of the RE technology market (Walker et al., 2007). Social sustainability benefits, on the other hand, may be related to the generation of stable income and social regeneration (Hain et al., 2005; Walker et al., 2007) or the tackling of fuel poverty in rural areas (Van der Horst, 2008).

The last type of influence has emerged in the research on how stakeholder influence may hinder the development of CRE, especially the political context and community acceptance of CRE schemes (Bomberg and McEwen, 2012; McLaren Loring, 2007; Musall and Kuik, 2011; Warren and McFadyen, 2010; Zoellner et al., 2008). Bomberg and McEwen (2012) suggested that community mobilization for $\mathrm{RE}$ is hindered by the political framework. With regard to community acceptance, authors seem to have confirmed that a community ownership approach can mitigate local opposition (McLaren Loring, 2007; Musall and Kuik, 2011; Warren and McFadyen, 2010; Zoellner et al., 2008). Painuly (2001) suggested that the RE technology industry, consumers, NGOs, experts, policymakers and professional associations are, in general, 
influential stakeholders with whom there should be interaction in order to overcome the barriers to RE deployment.

Although the literature highlighted above has brought out some influences of the stakeholders involved in local RE projects, to date there is still a gap in knowledge about who such actors are, what their interplay is, what role they play and why they assume these roles in the development of energy provision projects controlled by local communities. Filling this gap is relevant because it helps us to better comprehend how sustainable energy provision systems may be established.

\section{Data and methods}

\subsection{Data collection}

The data for this study were collected as part of the SECRE project, an international initiative aiming at building a functional and collaborative scheme to preserve the vitality of peripheries by using self-sustainable energy solutions (http://www.secre.eu/). The data acquired in the SECRE project consisted of 53 cases of CRE projects from Scotland, Finland, Northern Ireland, Ireland, Norway, Sweden and Germany. Different types of RE technology were taken into account, including hybrid technology ${ }^{1}$. All the cases were selected according to a maximum variation sampling method (Patton, 1990) to gain deep insights from different types of CRE projects. For each case, a detailed, structured interview was carried out by one of eight SECRE project staff members. The interview consisted of a total of 12 sections that included information on the origin of the idea, engagement with stakeholders, resource and technology evaluation, funding,

\footnotetext{
${ }^{1}$ Hybrid technology refers to a combination of different energy conversion technologies relying on more than one renewable energy source or a mix of renewable energy sources and fossil fuels.
} 
the implementation phase, community impressions upon completion of the project, running and monitoring the project, profitability, and community acceptance of the scheme. The set of questions was prepared by an international workgroup based on their previous experience. The same international workgroup also carried out a preliminary pilot test of the interview guide and the training of the interviewers. In most of the cases the interviews were recorded, but in a few cases permission for recording was not given and thus field notes were taken by the interviewer. After the notes and recordings had been processed, the transcripts were approved by the interviewees to ensure data reliability. All the interviews lasted between 60 and 90 minutes and were conducted from September 2012 to May 2013. A total of 56 interviewees participated in the study. They were project leaders (10), project founders (8), chairs of the trust (9), project developers (4), steering group members (3), volunteers (9), municipal officers (5), representatives of national authorities dealing with RE matters (3) and members of organizations providing support for CRE schemes (5). All the interviewees were selected on the basis of their level of experience and relevance to the governance of the projects.

The maximum variation sampling method employed generated a wealth of various types of CRE initiatives. To refine the sample, only cases that matched the categorization in Walker and Devine-Wright (2008) were selected. Consequently, those cases of CRE projects that were not open and participatory and that did not deliver benefits to the local community were excluded. As a result, out of all the studied cases (53 total), 41 were chosen to be the focus of this study. Table 1 summarizes the countries of origin of the selected cases and Table 2 summarizes the type of RE technology and organizational model used. 
Table 1

Studied CRE schemes and their countries/region of origin

\begin{tabular}{|l|c|}
\hline Country/Region & Number of Cases \\
\hline Scotland & 24 \\
\hline Germany & 6 \\
\hline Finland & 5 \\
\hline N. Ireland & 2 \\
\hline Sweden & 2 \\
\hline Ireland & 1 \\
\hline Norway & 1 \\
\hline Total & 41 \\
\hline
\end{tabular}

Table 2

Types of RE and organization

\begin{tabular}{|l|c|l|c|}
\hline Type of Technology & Number of Cases & Type of organization & Number of Cases \\
\hline \multirow{4}{*}{ Wind power } & \multirow{3}{*}{19} & Customer-owned company & 1 \\
\cline { 3 - 4 } & & Partnership with a developer & 4 \\
\cline { 3 - 4 } & & Social enterprise & 13 \\
\cline { 3 - 4 } & & Cooperative & 2 \\
\hline \multirow{2}{*}{ Biomass } & \multirow{2}{*}{11} & Cooperative & 8 \\
\cline { 3 - 4 } & & Social enterprise & 3 \\
\hline \multirow{2}{*}{ Hybrid technology } & \multirow{2}{*}{6} & Cooperative & 1 \\
\cline { 3 - 4 } & & Social enterprise & 3 \\
\hline Hydropower & 3 & Social enterprise & 1 \\
\hline Solar power & 1 & Cooperative & 1 \\
\hline Tidal power & 1 & Social enterprise & 41 \\
\hline Total & 41 & Total & \\
\hline
\end{tabular}

\subsection{Data analysis}

The written transcripts of the interviews and field notes related to the $41 \mathrm{CRE}$ cases were analysed by thematic analysis, which in the view of Braun and Clarke (2006, p. 79) is a "method for identifying, analysing, and reporting patterns (themes) within data." The themes emerging across the data were identified with a general inductive approach (Thomas, 2006). This approach allowed important themes to emerge from the raw data. The analysis focused on only the explicit meaning of the text. After close reading of the written transcripts of the interviews and field 
notes, coding started. Segments of text that appeared to be meaningful to the research question were coded in each single case by the one the authors. Subsequently, all the codes from the 41 cases were pieced together to see how they could potentially form an overarching theme. After this first phase of analysis, 544 thematic codes were generated. To increase the reliability of the coding procedure in the second stage of the analysis, another author checked that the coded text would fit the preliminary themes formed. The initial themes obtained were then reviewed and refined according to the principle of "internal homogeneity" and "external heterogeneity" (Patton, 2002, p. 465). As a result, new themes or subthemes were added while others were modified or deleted. The final step was to check that the name given to each of the themes reflected their essential characteristic (Braun and Clarke, 2006). Once we had the themes created based on the data, we integrated them with our stakeholder theoretical approach. In each theme we analysed which stakeholders were mentioned and how they influenced or were influenced by a CRE project. By analysing similarities and differences among themes, we constructed our final categories. Examples of coding categories and the corresponding stakeholders associated with each category are shown in Appendix A.

\section{Results}

The results of this study indicate that stakeholders influence or are influenced by CRE initiatives on three distinct levels: macro, intercommunity and intracommunity. Within the macro level, influential stakeholders were the government, energy suppliers, the network operator and commercial developers. At the intercommunity level, the relevant stakeholders were nearby communities and intermediary organizations. Finally, at the intracommunity level, the local community at large, people living near an installation, local project champions and businesses were identified as key stakeholders. 


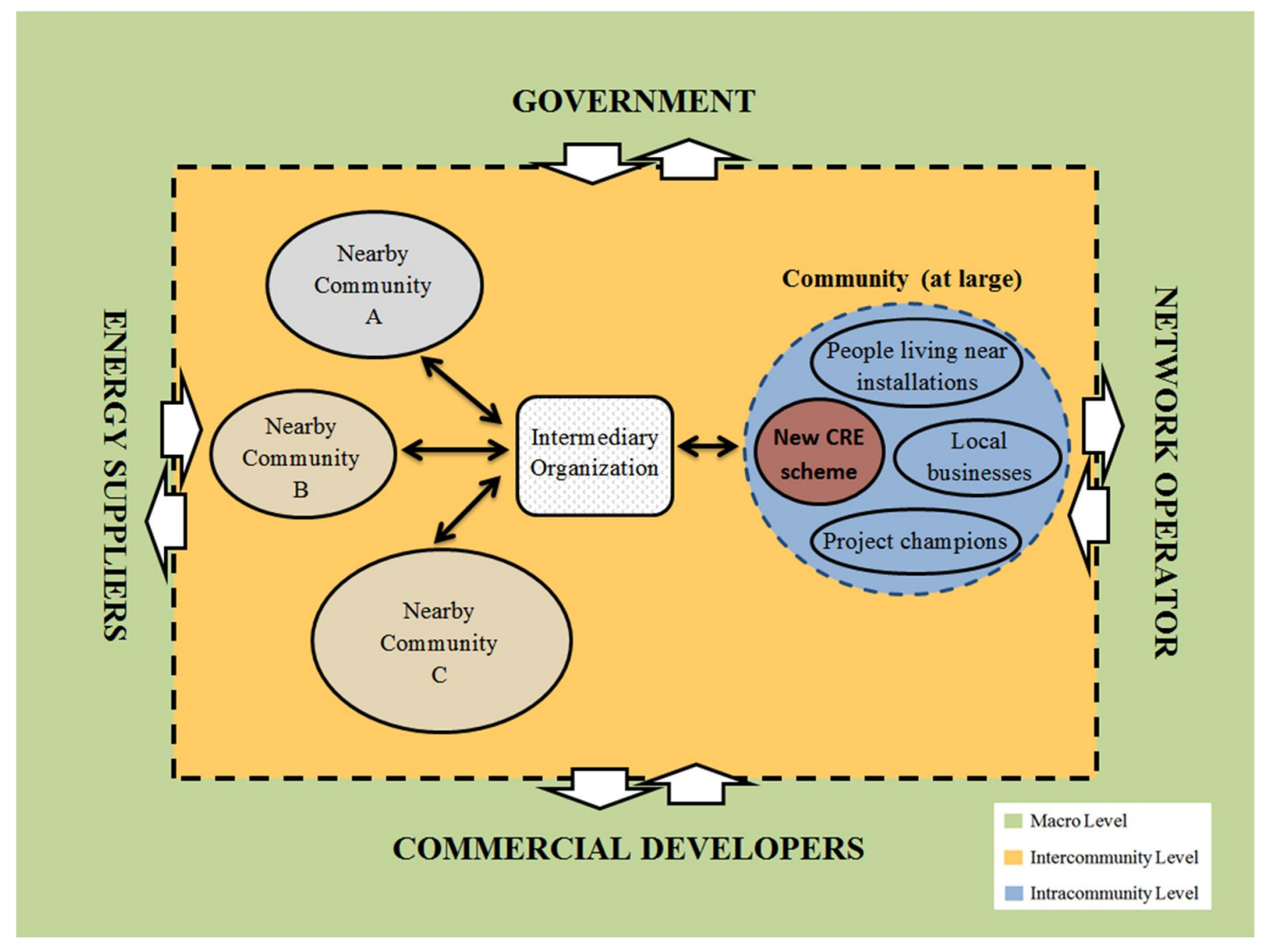

Fig. 1. Stakeholders having an influence on CRE projects at the macro, intercommunity and intracommunity levels (For color reproduction)

Figure 1 shows the interconnections of all the stakeholders identified at the three distinct levels of influence. The dashed line illustrates that the levels of influence do not have exact limits but instead exhibit fluid boundaries. All the stakeholders found had a strong influence in the development process of CRE, assuming sometimes a supportive role, a hindering role or both roles at the same time. In terms of project outcome these actors sometimes received a benefit and at other times they were harmed. Only in three cases were they simultaneously a beneficiary and a harmed stakeholder. In the following section we explain the role of each stakeholder and the main factors that made them assume a certain role or multiple roles at the same time in the developmental phase of a project (process) as well as after a project was completed (outcome). 


\subsection{Macro level}

\subsubsection{Government}

In all the countries investigated, national and local governments had implemented energy policies aiming to increase RE capacity. The governments were, however, both supportive stakeholders when making funding available and at the same time also hindering stakeholders when they were not able to ensure easy access to funding and a steady policy framework.

"Yes, opportunity that exists for the moment, i.e. grant funding..." (ID 21) "The government themselves are a negative influence. This is due to the frequent changes in legislation. This then puts back plans or plans have to be changed completely. Thus, delaying projects for long periods of time." (ID 26)

In the cases of CRE projects from Scotland, it was found that in certain instances up to $90 \%$ of grant funding was available. Grant mechanisms and other forms of government support were found to a less diffuse extent in the other countries as well. However, in the case of the Scottish government, policy seemed to play a prominent role in promoting CRE. Feed-in tariff mechanisms were considered by about one quarter of the respondents as one of the external factors supporting community projects. However, the uncertainty around the government policies concerning public support for RE stalled some projects for long periods, because the banks would not give any loan until the outcome of the new feed-in tariff system was clear.

"The change to feed-in tariff rules has stalled the whole industry for 18 months." (ID 26) 
The majority of the CRE schemes reviewed depended on government grants or bank loans. On the other hand, in one quarter of the cases community funds were also used to finance part of a project. This was noticed in the case of energy co-operatives in particular.

"Half of the money $€ 93,500$ came from capital from the cooperative... we were first turned down but when we put half the amount in the pot and reminded the bank that the people in the cooperative who wanted to borrow money already were customers of this bank..." (ID 39)

Community funds were rarely able to cover the entire costs of the investment but these funds often provided at least the start-up capital. The ability of a community to provide part of the start-up capital was considered in the majority of the cases as one of the most important factors influencing the decision of financial institutions to fund a community project.

\subsubsection{Energy suppliers}

The energy suppliers were companies responsible for the generation and, in some cases, the distribution and sale of electricity and heat. These stakeholders were indirectly supportive stakeholders of CRE initiatives due to the fact that in several countries they had increased the energy prices. Such increases had repercussions on the running costs of communal spaces, public halls and private households, a situation that led numerous communities to search for more affordable energy solutions. 
"The increasing price of oil and bills. Couldn't afford to keep going on paying these bills" (ID 43).

In Finland, for example, it was found that the energy price had increased at a rate of $10 \%$ per year. Steep energy prices seemed to be affecting particularly those rural remote communities which did not have access to the grid and that depended on diesel generators for power provision. In these instances, local residents embarked on a CRE project to save money by providing cheaper heat or power and to tackle fuel poverty. Fuel poverty was found to be an issue especially in rural remote areas where certain households did not have a connection to the network and could not afford to keep their homes warm at a reasonable price.

"The residents wanted affordable heat; we have fuel poverty within the development." (ID 57)

In terms of project outcome, it appeared that in Germany some energy suppliers were harmed by CRE projects because their market share was reduced due to the high number of community-led projects that had started.

\subsubsection{Network operator}

The network operator was a company responsible for the distribution of electricity or heat to a network. This actor was identified as a supportive as well as a hindering stakeholder in the process dimension of CRE and as both a beneficiary and a harmed stakeholder with respect to the project outcome. In very remote areas where certain communities were not connected to the 
national grid due to the lack of energy infrastructures, local residents were forced to initiate CRE projects to improve their living conditions.

"It was an obvious move. No grid connection is available to the mainland; we are offgrid, for the project we had to prove this... The project wasn't about being green it was about having power 24/7.” (ID 34)

However, similar initiatives were started in less remote communities as well, such as in the cases of community heat networks built by co-operatives in Finland and Germany. With regard to network operators, the data also showed that in many instances long delays in obtaining the connection to the grid hindered the completion of a project. Such delays were often associated with technical issues.

"The only issues the Trust had were the initial grid issues which held the project up." (ID 21)

In a few instances it also emerged that between community developers and a local network operator there were tensions when the latter hindered the connection to the network by increasing the network connection fee.

"Local electricity Grid Company tried to overprice the grid connection and thus prevented our activities.” (ID 17) 
With regard to project outcome, grid operators were beneficiary actors due to the network connection fees paid by project developers and also harmed stakeholders due to the impact of discontinuous RE sources on grid stability. When the grid was in danger of breaching safety limits due to overproduction or underconsumption of electricity, grid operators used generation curtailment. As a consequence, RE producers that had a non-firm grid connection had their output either trimmed or were switched off entirely. Generation curtailment harmed several wind power developers, causing loss of income for the projects because during the curtailment periods the generators could not claim the feed-in tariff.

\subsubsection{Commercial developers}

Commercial developers were companies specialised in building and operating large RE power plants. In the development of the CRE schemes these companies assumed a supportive role when they were interested in cooperating with local communities and a hindering role when they were competing for both government funding and good RE sites.

"The site was also wanted by a developer who wished to develop it as a commercial idea.” (ID 32)

To overcome conflicts in project development, some developers had established partnerships with local communities, which could buy shares in a project or own part of it. According to most of the respondents, these joint ventures were fruitful because local communities were not required to put together a funding package and they could thereby avoid bearing the economic risk of the project. Moreover, because experienced commercial companies provided all the 
technical know-how required, local communities did not need to acquire technical knowledge to carry out complex projects.

"I think the joint venture model is really interesting because of the removal of risk to the community. Because there was no requirement for the trust to become technically proficient and the level of administrative competence to progress a project like this from start to finish. Comparing it to other communities there are costs but it's better than $100 \%$ ownership, wouldn't have managed..." (ID 41)

With regard to project outcome, commercial developers were found to be a beneficiary stakeholder because of the income generated by co-owned projects with local communities and because of the enhanced reputation they gain when interested in developing a site together with local actors.

\subsection{Intercommunity level}

\subsubsection{Nearby communities}

In most of the cases nearby communities that had previously implemented a CRE scheme or that were completing one were identified as supportive and beneficiary stakeholders due to exchange of knowledge and experience. These exchanges of know-how triggered the implementation of new initiatives in neighbouring communities. Successful projects seemed to serve as a means to provide reassurance that CRE schemes were viable and could be replicated. 
“...there was an element that it had been done with communities that we looked at, so it was proven, it was repeatable." (ID 57)

The exchanges of know-how took place in regional networks where cooperation and the historical background of a community also played a crucial role. For instance, in Sweden it was found that village cooperation was a movement that had started already in the 1980s. Many clusters of villages already existed that worked together and shared their experiences in many joint initiatives, including RE generation. From the point of view of project outcome, most of the communities involved in this exchange of knowledge and experience benefited.

\subsubsection{Intermediary organizations}

Intermediary organizations were identified as supportive stakeholders through advice and guidance. They played a crucial role in providing support to inexperienced community groups that were carrying out RE projects.

"Community Energy Scotland has been very good for financial, legal and moral support." (ID 21)

The support provided in the developmental phase of a project included not only technical and legal advice but also guidance on funding sources and applications, provision of feasibility plans and collection of best practices from other communities. In a few cases these organizations also operated as an agent between a commercial developer and local community groups. 
"Community Energy Scotland had the idea of bringing [Company X] over to Orkney for three days to demonstrate turbines that were already in Orkney, to showcase contractors already here and introduce community and private developers that would form a potential market for them..." (ID 58)

In Scotland intermediary organizations were sometimes other social enterprises, such as in the case of Community Energy Scotland (www.communityenergyscotland.org.uk). In other countries intermediary organizations were found more in connection with the public sector, such as in the case of the Sustainable Energy Authority of Ireland (http://www.seai.ie/Home/). In other instances the local municipalities also played a role as intermediaries, as they did in the case of the establishment of some energy co-operatives in Finland. However, only in Scotland was it noted that the local intermediary organizations aimed expressly at capacity building and knowledge transfer.

\subsection{Intracommunity Level}

\subsubsection{Local community at large}

The local community at large was identified as a supportive stakeholder due to three main factors: availability of material resources, community ownership as well as a general positive attitude to CRE development. The material resources given to the project consisted of RE sources and access to land. The presence of RE sources was found both as a by-product of another activity, such as excess heat from agricultural biomass power plants, or as naturally occurring resources, such as the presence of a nearby river for hydropower generation. With regard to land access it was found that projects were favoured when there was an agreement 
between the estate owners and the development group or when the issues concerning land lease or purchase were sorted out in the early phase of a project.

"The land lords were in full support of the community trust and thus we did not need to buy out the land." (ID 21)

In the largest number of cases, community ownership was associated with community support. This association was often demonstrated by the fact that planning permits were issued without any objection or because in certain communities there had been a poll by which citizens were asked to vote whether they supported the project or not and often the results were in favour.

"There were no planning issues. The local council granted planning. The community was always in agreement with the Trust and the renewable project. This is because it is a community owned RE project and it is for community benefit. This would not be the case if it were a commercial developer." (ID 26)

Several respondents seemed to believe that local ownership of RE generation was a way to control the energy future of their community. This aspect was particularly evident in those remote communities that did not have access to a network.

"It is an investment in the future of the village as it makes it more independent from external energy suppliers and provides the possibility to shape our own future with ecologic energy." (ID 74) 
In the majority of the projects reviewed it was found that the community at large had a positive attitude towards CRE schemes. This positivity appeared to be associated with expected positive benefits, reduction of energy costs, alleviation of fuel poverty and the possibility to determine one's own energy future. In a very few cases the community at large was also found to be a hindering stakeholder. This was mainly due to the scepticism of some community members who had doubts about the viability of the projects and concerns about their possible impact. These views gradually changed after a project was completed.

\footnotetext{
"Once the plant was operational, the first views were negative, but they started to change quite rapidly once they noticed that there aren't any harmful side-effects such as noise, pollution, etc.” (ID 69) “...the doubters were quieted.” (ID 53)
}

With regard to project output, local communities were identified as beneficiary stakeholders through economic development, an enhanced sense of self-sufficiency, community identity, sustainability and start-up capital. Economic development was supported by the income generated by the projects that, in the majority of the cases, were found to be profitable. In more than half of the cases the flow of income generated was mainly used to pay back the loans while part of it was reinvested in the community. In certain instances the profits were purposely reinvested in developing more RE initiatives, energy conservation projects or environmental protection programs for the collective. In other circumstances community enterprises aimed at establishing their own funding schemes by which social initiatives or businesses could be promoted. 
"It is printed in the articles of association: we are not distributing profits and all profits are used towards new wind energy investments. Thus we had worked so far towards the purpose of developing new wind turbine areas...” (ID 17)

Economic development was associated not only with the direct earnings emerging from the sale of RE to the network and the feed-in tariff mechanism, but also with the generation of new jobs from the schemes either directly or indirectly. The economic development theme emerged in almost all the cases, and the themes of self-sufficiency and identity were particularly recurrent in rural remote areas.

"The need to try to redress the dwindling population of the island and awareness that we can't rely on grant funding. Having an identity and something to be proud of." (ID 32)

In almost one-tenth of the cases it was found that CRE projects also harmed some communities due to ill-feelings emerging among local residents, contrasting interests or lack of trust in the people who were promoting a community RE project.

\subsubsection{Local businesses and people living near installations}

Although in the majority of the cases local communities played a supportive role in the development of CRE schemes, in a small number of cases it was found that within a community there was also some opposition. Typically two groups of stakeholders had an interest in opposing a project. The first group included local businesses. According to this group of stakeholders, community enterprises running RE generation projects harmed them because these new enterprises were seen as competitors. Consequently this group of stakeholders opposed the projects during the developmental phase. 
“...opposition from the local business community, saw them, as competition.” (ID 61)

Nevertheless, in many other cases local businesses also supported CRE development because it created new business opportunities for, among others, local contractors, small maintenance companies or farmers providing wood. In this case, local businesses were beneficiary stakeholders due to the income generated by new business opportunities.

"A local grid company looks after the wind turbine park. This gives about a $50 \%$ job position in this company." (ID 31)

The second group of stakeholders who played a hindering role through their opposition consisted of local people living near an installation. The actors raised many arguments against project development, especially in the case of wind power, as they were directly harmed by the impact of an RE installation from noise and by the affected value of the landscape.

"Some resistance around wind turbine and the aesthetics of the site, nervousness around noise issues from immediate neighbours...” (ID 56)

\subsubsection{Local project champions}

Local project champions were members of a local community who had a prominent role in starting, endorsing or carrying out a project. They emerged as a separate group of stakeholders from the community at large, because not all the community members were actually involved in 
a project. Local champions were supportive through primarily their individual values, skills and competencies.

While the local community at large possessed relevant material resources, project promoters sometimes owned relevant non-material resources. These non-material resources included a stock of skills, competencies and personality traits that, in certain cases, promoted CRE deployment.

"He had technical skills as an engineer and found the location very promising for a wind turbine park. He did all the preparation work for the Norwegian authorities." (ID 31).

On the other hand, CRE development was hindered when project champions lacked essential skills and competences. This was found in the majority of the cases because the people involved in community projects were mostly inexperienced. Project champions often lacked technical competences not only in RE technology but also in finance, funding issues, project management, law, marketing and business management.

"Firstly, there was a lack of expertise. The Community Trust is made up of local community members. They did not realise how complicated setting up a renewable project would be, they go into this thinking that renewables are an easy way to earn a sustainable source of income for the community. They are not renewable experts and have to learn as they go along." (ID 32) 
Project champions' values were an important factor supporting local RE initiatives. The first set of values identified was volunteering for the initiative as a project promoter. Often the founding members or the initiators were the real driver behind the initiatives. Recurrent attributes such as being active, determined, and hands-on were associated with these subjects who often worked as volunteers. Volunteers were involved in many tasks, including planning, implementation and management.

“...the villagers are hands-on guys with many handymen among them. Therefore, almost the entire work, except for the heating system, could be done through voluntary work." (ID 72)

The second set of values identified was the willingness to act for the environment. In several cases people got involved in RE generation because they felt the need to do something for the natural environment and reduce their $\mathrm{CO} 2$ emissions. For instance, some communities were relying on unsustainable energy sources such as diesel fuels or peat. In some instances the implementation of an RE scheme fitted the general goal of a local community to promote sustainable development.

"They felt they were unsustainable as they were..." (ID 61)

The last group of values identified as an internal driver for the local champions was associated with the desire to demonstrate the viability of RE projects for the benefit of the community or to experiment with RE technology. This was the case for a community group in Sweden that started one of the first wind power co-operatives in the country: 
"Five persons stated that there was no wind power plant in Sweden and we decided to become pioneers and build one to produce our own electricity..." (ID 66)

In terms of project outcome, local champions were beneficiary stakeholders because in many instances they learned a lot after a project was completed. Often the missing skills were learned through experience in the field. In addition, in the cases of project champions who were members of co-operatives that returned surpluses, they were also beneficiary stakeholders due to the income they earned.

Table 3 in Appendix B summarizes the findings of the study. The table describes the roles assumed by the stakeholders identified and the factors triggering such roles with respect to the process and outcome dimensions of CRE projects. Furthermore, all the stakeholders are also classified according to their level of influence, that is, macro, intercommunity and intracommunity.

\section{Discussion}

The results of this study showed that during the implementation phase (the process dimension) stakeholders can influence a project by playing a supporting and/or hindering role and have, thus, the potential to be beneficiary or harmed stakeholders. However, once a CRE scheme is established, these stakeholders may experience the benefit or be harmed (the outcome dimension) and may accordingly change their position as a supportive or hindering stakeholder. For instance, at the intracommunity level the local community at large may have concerns about 
the viability and the real benefits of CRE schemes, but when a project is completed and the positive outcomes are experienced their views can change. Similarly, a network operator may (indirectly) contribute to the establishment of CRE schemes and have a benefit in terms of income from network connection fees, but its role may change when it sees a threat to grid stability. These findings can be seen in the light of what Freeman (1984) and Mitchell et al. (1997) call stakeholder dynamics. Moreover, compared with what Bourne and Walker (2005) pointed out - stakeholders can influence project outcomes - we find that stakeholders can influence project outcomes but that outcomes can also influence stakeholders.

Another important point that emerged from the results was that at the macro level, the government can be a hindering stakeholder when creating barriers to funding access or when not able to ensure a steady policy framework. However, it can also be a supportive stakeholder and have benefits in terms of increased capacity in the outcome phase. This finding demonstrates that stakeholders sometimes assume multiple or even conflicting roles and it is in line with the suggestion by Bomberg and McEwen (2012) that structural resources (the political framework) have a dual function in promoting and also hindering CRE initiatives. Thus, even though the role of some stakeholders can be fairly predicted (e.g., people living near installations directly harmed by a project outcome express opposition in the developmental phase) in other cases stakeholders influence on a CRE project is less predictable. This is the case of network operators or local businesses that may see CRE development as a threat and also as an opportunity.

Another important contribution of this study is the creation of a framework to analyse stakeholders' influence on CRE projects. Figure 1 shows the interconnection between the 
stakeholders and their levels of influence. Within this framework the study highlighted some important country differences in regards to stakeholder influence across the seven regions considered. To illustrate, while there was a wider trend in which energy prices increased the desire of local communities to reduce their energy costs, in Germany and Scotland stakeholder influence on CRE schemes at the macro level was more determined by ideological or political views. Our findings are consistent with Buchan (2012) and Seyfand and Smith (2007). Moreover, in Germany the political and ideological influence behind the high number of citizenled initiatives brought about a new scenario in which the energy companies were starting to lose market shares. This important element shows that grassroots innovation for RE generation and provision may lead to changes in the traditional business model of electric utilities in the near future. On the other hand, because under a widespread community-based scenario energy suppliers may have only a negative outcome, it is also possible to expect that these stakeholders may cause lock-ins in the process of replicating CRE generation on a larger scale.

In contrast to Germany, in remote areas of Scotland, Norway, Sweden and Finland stakeholder influence on CRE schemes was triggered more by issues connected to energy needs. In these regions CRE development may expand rapidly if network operators do not invest in new energy infrastructure to reach off-grid customers and the cost of RE technology continues to decline. On the other hand, however, more attention should be given to the strengthening and reinforcement of the grid as the more new renewable power is fed into the grid, the more network operators may be harmed by grid instability and, in turn, the more CRE developers may be penalized. In this regard, some possible solutions to reduce the consequences of variable output of intermittent resources and to reduce the risk that network operators apply in generation curtailment are the 
inclusion of energy storage devices into the electricity supply system and the promotion of flexibility in electricity consumption.

The final important contribution of this study is that it revealed the important role of local champions and intermediary organizations across the seven regions studied. Local champions have a prominent influence on CRE projects, and their role has been discussed previously in other fields of study, such as environmental management (Pollock and Whitelaw, 2005; Elbakidze et al. 2010; Yaffee and Wondolleck, 2000), but it has not yet been illustrated in CRE initiatives. These actors are driven by their values and give their time for the development of a project. However, despite their ability to make things happen, in most of the cases they are inexperienced or lack the proper skills to carry out RE projects.

As for intermediary organizations, their role in the RE context has been discussed in only two previous studies, by Kivimaa (2012) and Hargreaves et al. (2013), in which these organizations were described in the context of public-private sector interaction and grassroots innovation. We found that while intermediary organizations have an essential function in terms of knowledge transfer and capacity building, they emerge in response to different kinds of institutional backgrounds and needs. Our data, unfortunately, did not allow us to find specific information on the potential differences between these types of organizations which in certain cases appear as being more linked to government and in others to be more "neutral" (Kivimaa, 2012, p. 1338).

Our findings concerning the link between ownership and community support confirm other previous research by McLaren Loring (2007), Zoellner et al. (2008), Warren and McFadyen 
(2010), and Musall and Kuik (2011). In addition, they are in line with Li et al. (2013), Phimister and Roberts (2012) and Rogers et al. (2008) with respect to the relationship between CRE schemes and socioeconomic development. In relation to community benefits, this study highlighted another important aspect that has not been discussed in studies on CRE generation: the role of local communities in providing start-up capital for RE projects. Although most of the initiatives studied depended on government grants and bank loans, in a good number of cases it was found that the projects were almost completely self-financed, especially in the case of cooperatives. This aspect is fundamental for RE deployment, which still relies heavily on state subsidies. Crowdfunding could offer one alternative to a post-subsidized RE economy in the near future.

This study also has a few limitations. These originate primarily from the method chosen for data collection and in the theoretical perspective. In truth, due to the high number of cases analysed, part of the context in which the cases were originally imbedded was unavoidably lost. The stakeholder approach led us to develop a preliminary understanding of stakeholder influence in CRE generation. However, more qualitative research on the experiences of local champions focusing on their motivations for acting and their inhibitors would be required to better comprehend the role of this key actor group. Some case studies could better clarify how communities learn from each other. Finally, other research is also needed to understand what the most crucial phases of CRE projects are and what role stakeholders play at each stage of project development.

\section{Conclusions and policy implications}


This study showed how stakeholders may influence the development of CRE projects (process dimension) and how they are influenced by their outcome. Stakeholder influence on CRE schemes takes place at three distinct levels: macro, intercommunity and intracommunity. Stakeholders do not simply influence the development of CRE schemes by supporting or hindering them, but they can play both roles simultaneously. In addition, key stakeholders can support or hinder the development of a project according to whether or not they perceive that the output of the project may benefit or harm them. This characteristic was found at the intracommunity level in particular, where how a CRE scheme is perceived depends on the direct benefits that the community at large receives from the project. However, these views are not fixed and can change after a project has been completed. On the other hand, if stakeholders have only negative outcomes, they will have a hindering role in the development of CRE schemes. This was, for example, the case with people living near an installation. If stakeholders have both positive and negative outcomes, they may still hinder but their actions may have less impetus due to the benefits that are at stake. This was, for instance, the case of network operators.

A general stakeholder framework was also created to better understand the interplay of key actors. Based on this stakeholder framework we realise that the governments should ensure easier access to funding and a stable policy support to CRE projects. Conversely, at the macro and intracommunity level more ad hoc policies are needed to promote the successful integration of small-scale RE generation into the grid. Such policies should support, in particular, energy storage and demand-side management. At the intercommunity level, national and regional regulatory bodies should increase knowledge transfer through the establishment of intermediary organizations. 
The study also showed the importance of local champions. These stakeholders have significant non-material resources that are able to unlock the potential material resources held by the community at large and stimulate local socioeconomic development. However, it was also revealed that while these actors are supported by their values, they may often lack technical skills and competencies. Thus, at the intracommunity level policy mechanisms should allow the transfer of essential technical skills to ambitious local champions. Finally, more countries could follow the example of the United Kingdom, which encourages social enterprises in CRE generation. As social enterprises reinvest their surpluses in the community and in RE development, they may become a means to tackle fuel poverty in rural areas and they may also contribute to the expansion of RE capacity. 
Appendix A. Examples of coding categories and the corresponding stakeholders.

\begin{tabular}{|c|c|c|c|}
\hline Stakeholder & Theme & Subtheme & Sample quotes \\
\hline Government & $\begin{array}{l}\text { Available funding } \\
\text { Difficulties in } \\
\text { accessing funding } \\
\text { Unsteady regulatory } \\
\text { framework }\end{array}$ & Feed-in tariff & $\begin{array}{l}\text { "Availability of grants for such projects", } \\
\text { "The change to feed-in tariff rules has stalled } \\
\text { the whole industry for } 18 \text { months", "Funding } \\
\text { planning process, initially recommended for } \\
\text { refusal, a very hard and difficult time for the } \\
\text { board personally" }\end{array}$ \\
\hline Energy supplier & High energy price & $\begin{array}{l}\text { Fuel poverty } \\
\text { Energy costs }\end{array}$ & $\begin{array}{l}\text { "...increasing price of oil and bills. Couldn't } \\
\text { afford to keep going on paying these bills", } \\
\text { "The fact that the residents wanted } \\
\text { affordable heat, we have fuel poverty within } \\
\text { the development..." }\end{array}$ \\
\hline Local businesses & Opposition & Competition & $\begin{array}{l}\text { "Some opposition from local business } \\
\text { community, saw them as competition" }\end{array}$ \\
\hline $\begin{array}{l}\text { People living near } \\
\text { installations }\end{array}$ & Opposition & $\begin{array}{l}\text { Impact on health due } \\
\text { to noise } \\
\text { Affected value of the } \\
\text { landscape }\end{array}$ & $\begin{array}{l}\text { "Some resistance around wind turbines and } \\
\text { the aesthetics of the site, nervousness around } \\
\text { noise issues from immediate neighbours" }\end{array}$ \\
\hline
\end{tabular}




\section{Appendix B. Table 3}

Summary of the findings of the study

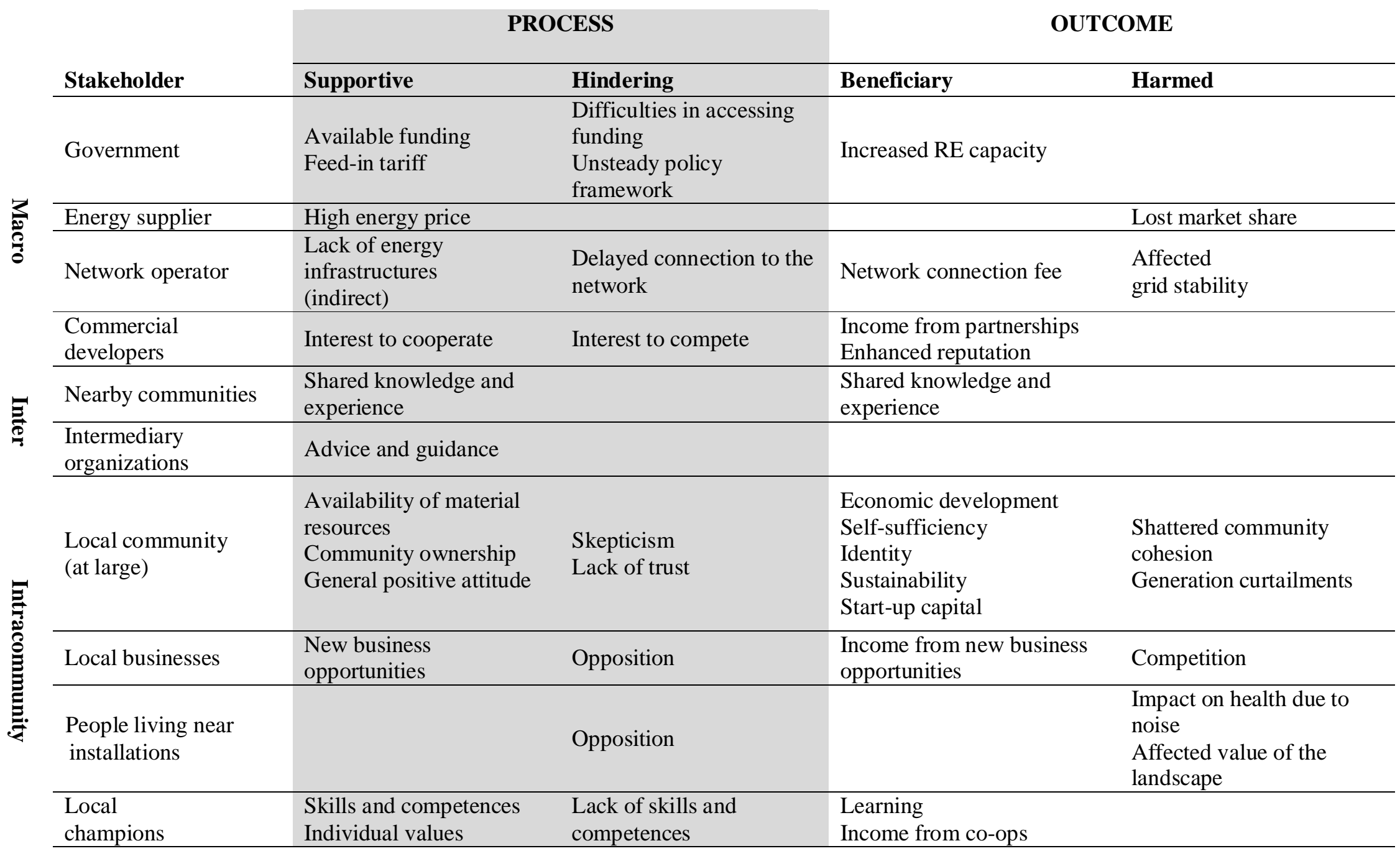




\section{References}

Aitken, M., 2010. Wind power and community benefits: Challenges and opportunities. Energy Policy 38 (10), 6066-6075.

Banerjee, S.B., 2000. Whose land is it anyway? National interest, ingenious stakeholders, and colonial discourses. Organization \& Environment 13 (1): 13-38.

Banerjee, S.B., Bonnefous, A., 2011. Stakeholder management and sustainability strategies in the French nuclear industry. Business Strategy and the Environment 20 (2), 124-140.

Barnett, M., 2007. Stakeholder influence capacity and the variable of financial returns to corporate social responsibility. Academy of Management Review 32 (3): 794-816.

Berardi, U., 2013. Stakeholders' influence on the adoption of energy-saving technologies in Italian homes. Energy Policy 60, 520-530.

Berman, S., Wicks, A., Kohta, S., Jones, T., 1999. Does stakeholder orientation matter? The relationship between stakeholder management models and firm financial performance. Academy of management journal 42 (5), 488-506.

Bomberg, E., McEwen, N., 2012. Mobilizing community energy. Energy Policy 51, 435-444.

Bourne, L.,Walker, D., 2005. Visualising and mapping stakeholder influence. Management decision 43 (5), 649-660.

Braun, V., Clarke, V., 2006. Using thematic analysis in psychology. Qualitative Research in Psychology 3 (2), 77-101. 
Bristow, G., Cowell, R., Munday, M., 2012. Windfalls for whom? The evolving notion of 'community' in community benefit provisions from wind farms. Geoforum 43 (6), 11081120.

Buchan, D., 2012. The Energiewende-Germany's gamble. Oxford Institute for Energy Studies. Retrieved on the $7^{\text {th }}$ of January 2014 from: http://www.oxfordenergy.org/wpcms/wpcontent/uploads/2012/07/SP-26.pdf

Cass, N., Walker, G., 2009. Emotion and rationality: The characterisation and evaluation of opposition to renewable energy projects. Emotion, Space and Society 2 (1), 62-69.

Cass, N., Walker, G., Devine-Wright, P., 2010. Good Neighbours, Public Relations and Bribes: The Politics and Perceptions of Community Benefit Provision in Renewable Energy Development in the UK. Journal of Environmental Policy \& Planning 12 (3), 255-275.

Delmas, M.A., Toffel, M.W., 2008. Organizational responses to environmental demands: opening the black box. Strategic Management Journal 29 (10), 1027-1055.

Donaldson, T., Preston, L.E., 1995. The stakeholder theory of the corporation: Concepts, evidence, and implications. Academy of management Review 20 (1), 65-91.

Elbakidze, M., Angelstam, P.K., Sandström, C., Axelsson, R., 2010. Multi-Stakeholder Collaboration in Russian and Swedish Model Forest Initiatives: Adaptive Governance Toward Sustainable Forest Management? Ecology \& Society 15 (2), 1-20.

Freeman, R., 1984. Strategic Management: A Stakeholder Approach, Pitman, Massachusetts. 
Frooman, J., 1999. Stakeholder influence strategies. Academy of management review 24 (2), 191-205.

Hain, J.J., Ault, G.W., Galloway, S. J., Cruden, A., McDonald, J.R., 2005. Additional renewable energy growth through small-scale community orientated energy policies. Energy Policy 33 (9), 1199-1212.

Hargreaves, T., Hielscher, S., Seyfang, G., Smith, A., 2013. Grassroots innovations in community energy: The role of intermediaries in niche development. Global Environmental Change 23 (5), 868-880.

Henriques, I., Sadorsky, P., 1999. The Relationship between Environmental Commitment and Managerial Perceptions of Stakeholder Importance. The Academy of Management Journal $42(1), 87-99$.

Hoffman, S.M., High-Pippert, A., 2005. Community Energy: A Social Architecture for an Alternative Energy Future. Bulletin of Science, Technology \& Society 25 (5), 387-401.

Kivimaa, P., 2014. Government-affiliated intermediary organisations as actors in system-level transitions. Research Policy 43 (8), 1370-1380.

Li, L.W., Birmele, J., Schaich, H., Konold, W., 2013. Transitioning to Community-owned Renewable Energy: Lessons from Germany. Procedia Environmental Sciences 17, 719-728.

Lovio, R., 2004. Yrityksen sidosryhmät ja ympäristöjohtaminen, in: Heiskanen, E., (Eds), Ympäristö ja liiketoiminta. Arkiset käytännöt ja kriittiset kysymykset, Gaudeamus, Helsinki, pp. 53-68. 
McLaren Loring, J., 2007. Wind energy planning in England, Wales and Denmark: Factors influencing project success. Energy Policy 35 (4), 2648-2660.

Mitchell, R.K., Agle, B.R., Wood, D.J. 1997. Toward a Theory of Stakeholder Identification and Salience: Defining the Principle of Who and What Really Counts. The Academy of Management Review 22 (4), 853-886.

Munday, M., Bristow, G., Cowell, R., 2011. Wind farms in rural areas: How far do community benefits from wind farms represent a local economic development opportunity? Journal of Rural Studies 27 (1), 1-12.

Musall, F.D., Kuik, O., 2011. Local acceptance of renewable energy-A case study from southeast Germany. Energy Policy 39 (6), 3252-3260.

Näsi, J., 1995. What is Stakeholder Thinking? A Snapshot of a Social Theory of the Firm, in: Näsi, J., (Eds.) Understanding Stakeholder Thinking. Gummerus Kirjapaino, Jyväskylä, pp. $19-32$.

Okkonen, L., Suhonen, N., 2010. Business models of heat entrepreneurship in Finland. Energy Policy 38 (7), 3443-3452.

Painuly, J.P., 2001. Barriers to renewable energy penetration; a framework for analysis. Renewable Energy 24 (1), 73-89.

Patton, M.Q., 1990. Qualitative Evaluation and Research Methods, London, Sage.

Patton, M.Q., 2002. Qualitative Research \& Evaluation Methods, SAGE Publications. 
Phimister, E., Roberts, D., 2012. The Role of Ownership in Determining the Rural Economic Benefits of On-shore Wind Farms. Journal of Agricultural Economics 63 (2), 331-360.

Pollock, R.M., Whitelaw, G.S. 2005. Community-Based Monitoring in Support of Local Sustainability. Local Environment 10 (3), 211-228.

Rogers, J.C., Simmons, E.A., Convery, I., Weatherall, A., 2008. Public perceptions of opportunities for community-based renewable energy projects. Energy Policy 36 (11), 4217 4226.

Rogers, J.C., Simmons, E. A., Convery, I., Weatherall, A., 2012. Social impacts of community renewable energy projects: findings from a woodfuel case study. Energy Policy 42, 239247.

Rowley, T., 1997. Moving beyond dyadic ties: a network theory of stakeholder influences. Academy of management review 22 (4), 887-910.

Rowley, T., Moldoveanu, M., 2003. When will stakeholder groups act? An interest- and identitybased model of stakeholder group mobilization. Academy of management review 28 (2), 204-219.

Seyfang, G., Smith, A., 2007. Grassroots innovations for sustainable development: Towards a new research and policy agenda. Environmental politics 16 (4), 584-603.

Sharma, S., Henriques, I., 2005. Stakeholder influences on sustainability practices in the Canadian forest products industry. Strategic Management Journal 26 (2), 159-180. 
Spitzeck, H., Hansen, E., 2010. Stakeholder governance: how stakeholders influence corporate decision making. Corporate Governance 10 (4), 378-391.

Thomas, D.R., 2006. A general inductive approach for analysing qualitative evaluation data. American Journal of Evaluation 27, 237-246

Tracey, P., Phillips, N., Haugh, H., 2005. Beyond philanthropy: Community enterprise as a basis for corporate citizenship. Journal of Business Ethics 58 (4), 327-344.

Van der Horst, D., 2008. Social enterprise and renewable energy: emerging initiatives and communities of practice. Social Enterprise Journal 4 (3), 171-185.

Walker, B. J. A., Wiersma, B., Bailey, E., 2014. Community benefits, framing and the social acceptance of offshore wind farms: An experimental study in England. Energy Research \& Social Science 3, 46-54.

Walker, G., Hunter, S., Devine-Wright, P., Evans, B., Fay, H., 2007. Harnessing community energies: explaining and evaluating community-based localism in renewable energy policy in the UK. Global Environmental Politics 7 (2), 64-82.

Walker, G., 2008. What are the barriers and incentives for community-owned means of energy production and use? Energy Policy 36 (12), 4401-4405.

Walker, G., Devine-Wright, P., 2008. Community renewable energy: What should it mean? Energy Policy 36 (2), 497-500. 
Warren, C. R., McFadyen, M., 2010. Does community ownership affect public attitudes to wind energy? A case study from south-west Scotland. Land Use Policy 27 (2), 204-213.

Yaffee, S.L., Wondolleck, J.M., 2000. Making Collaboration Work: Lessons from a comprehensive assessment of over 200 wideranging cases of collaboration in environmental management. Conservation in Practice 1 (1), 17-24.

Zoellner, J., Schweizer-Ries, P., Wemheuer, C., 2008. Public acceptance of renewable energies: Results from case studies in Germany. Energy Policy 36 (11), 4136-4141. 